\title{
O SAGRADO E A RELIGIOSIDADE: VIVÊNCIAS E MUTUALIDADES
}

\section{Sacred and religiosity: experiences and mutualities}

\author{
Euclides Marchi*
}

\begin{abstract}
RESUMO
O objetivo deste texto é resgatar algumas concepções de sagrado e verificar como elas se articulam com a prática da religiosidade. A presença do sagrado e da religiosidade desafia os esforços da ciência e da tecnologia para explicar racionalmente o mundo e a existência humana. Apesar dos avanços e conquistas da ciência, o sagrado e a religiosidade mantiveram-se presentes e se afirmam como formas de vivenciar a religião para significativa parcela da população humana. No Brasil, essa presença revela-se na trajetória do catolicismo e nas articulações de ritos e práticas litúrgicas de múltiplas tendências religiosas e fazem surgir diferentes modalidades de convivência com o sagrado e maneiras originais de vivenciar a espiritualidade.
\end{abstract}

Palavras-chave: sagrado; religiosidade; rituais e crenças religiosas.

\begin{abstract}
This article aims at rescuing some sacred conceptions and verify its relation with the religious practice. The sacred and religiosity presence challenge sciences and technology efforts to rationally explain the world and the human existence. Although there were advances and conquests in science, the sacred and the religiosity were kept always present and they became the ways to a significant human population part live religion. In Brazil, this presence is revealed in the Catholicism trajectory, as well as in the liturgical practices and rites articulations in multiple religious tendencies. This presence created different modalities of living with the sacred and original ways of living spirituality.
\end{abstract}

Key-words: sacred; religiosity; rites and religious beliefs.

* Professor Sênior dos cursos de Pós-Graduação em História da Universidade Federal do Paraná, diretor do Núcleo de Ciências Humanas e Sociais Aplicadas do Centro Universitário Positivo, membro do Núcleo Paranaense de Pesquisas em Religião. 
O tema “o sagrado e a religiosidade” remete ao texto de Joel Birman ao comentar a obra A literatura e os deuses, de Roberto Calasso: “Onde estão os deuses? Quais são os seus percursos? De que maneira reconhecemos as suas presenças? Essas podem parecer perguntas ingênuas no mundo desencantado em que vivemos, se bem que o retorno da religiosidade nas últimas décadas também possa nos fazer crer que eles estariam finalmente de volta”. ${ }^{1}$

Franz Brüseke, ao trabalhar com o sagrado na modernidade técnica, ressalta:

\begin{abstract}
A técnica moderna coloca o homem em contato com o mundo que faz com que os Deuses fujam. Os Deuses não estão somente mortos, eles foram, segundo a metáfora de Heidegger, afugentados pelo homem moderno. Ou para lembrar Nietzsche: “Gott ist tot. Und wir haben ihn getötet!” (Deus está morto e nós o matamos). As duas metáforas, a primeira da fuga dos Deuses e a segunda que nos acusa do assassinato de Deus, correspondem àquilo que Weber expressa, de forma menos dramática, na sua tese do desencantamento (Entzauberung) do mundo. Este desencantamento é resultado imediato do processo de racionalização e intelectualização, sem o qual a ciência moderna não teria surgido. ${ }^{2}$
\end{abstract}

Como interpretar a afirmação de Nietzsche? O que estaria pensando Heidegger? O mundo estaria realmente desencantado, conforme nos propõe Weber? Metafóricas ou não, essas provocações induzem a outras reflexões sobre a maneira como as divindades e a sacralização do mundo poderiam resistir ao progresso científico e tecnológico contemporâneo.

Sem a pretensão de responder a estas questões, forçoso é pensar que a luta pelo desencantamento do mundo e o ataque ao pensamento mágico somente seria completo se o desenvolvimento científico conseguisse impor à sociedade uma única compreensão de mundo, despida de imaginários e controlada racionalmente. 0000189-_v.htm>

1 BIRMAN, Joel. A língua dos deuses. Disponível em: <www2.uerj.Br/ clipping/

2 BRÜSEKE, Franz. O sagrado na modernidade técnica. Cadernos de pesquisa interdisciplinar em Ciências Humanas, Florianópolis, n. 70, p. 16, maio 2005. (disponível na internet) 
Com muita freqüência a literatura insinua que, desvendados todos os segredos, o mundo material tornar-se-ia cientificamente compreensível e explicável. Nele, a física se encarregaria de tratar da matéria e da energia, a sociologia cuidaria de revelar os complexos mecanismos da construção social e as demais ciências assumiriam a tarefa de explicar os múltiplos componentes da vida e do universo. Por sua vez, valendo-se dessa nova modalidade de conhecimentos e dos novos mecanismos científicos e tecnológicos, o homem submeteria o mundo aos seus desejos e prescindiria das explicações mágicas e fantasiosas. Nesse contexto, qualquer sentimento ou ato que refletisse uma relação entre o homem e o sagrado estaria reservado ao mundo do imaginário.

Todo esse esforço faria sentido se, paralelamente ao controle do universo pela ciência, também fosse possível submeter o sagrado a um processo de racionalização e, ao mesmo tempo, anular o sentido religioso da vida. Em outras palavras, seria dessacralizar o mundo e suprimir o pensamento religioso do conjunto das explicações da existência e dos sentimentos do homem.

No decorrer dos séculos XVIII e XIX, cientistas de diferentes campos do saber e de múltiplas tendências filosóficas e teóricas contribuíram para o desenvolvimento de idéias e teses que explicassem os segredos da matéria e superassem os limites do conhecimento. Tudo levava a crer que o sentimento religioso entraria num processo de corrosão e que a sociedade evoluiria para a secularização, especialmente quando o crescimento industrial, a urbanização e o avanço tecnológico na produção de bens de consumo ditavam outros padrões de vida e influenciavam o comportamento das pessoas.

As novas descobertas e as invenções tecnológicas impuseram uma velocidade aos acontecimentos que, ao contrário do que se propunha, diminuíram ainda mais o tempo para se refletir sobre o "fazer do homem”, sobre as “coisas da vida”, sobre suas certezas e incertezas. O inusitado provocava uma mudança de paradigmas, dificultando até mesmo a compreensão dos caminhos da razão e da cultura. Múltiplas possibilidades a favor e contra o homem davam ao tempo outra velocidade, que parecia parar ou correr em demasia. As energias se esgotavam e não conseguiam dominar a volatilidade das exigências da vida.

E, ao se buscar uma explicação do mundo e da sociedade pela via única da racionalidade, esbarrou-se num fato objetivo: as pessoas continua- 
vam a contemplar o “extra-ordinário”, preservavam a crença naquilo que estava fora do cotidiano e das coisas comuns nas quais se expressava uma ordem sagrada que dava sentido às suas vidas, aos lugares e à sua concepção de mundo. Elas continuavam a mitificar o tempo e o espaço do sagrado.

No século XX, a sociedade defrontou-se com dois desafios: de um lado, alguns intelectuais declaravam a morte de Deus e tentavam suprimir qualquer explicação não racional da existência humana e do universo, e de outro, a permanência do sagrado nas manifestações da religiosidade, na cultura, nas artes e nos múltiplos setores da organização social. Parte significativa da humanidade manteve vínculos com os deuses e com outras entidades e assim organizava suas crenças, ordenava suas experiências de vida e suas práticas religiosas. Tais vínculos não necessariamente passavam pelo controle das organizações eclesiásticas e o contato com os deuses suplantava os liames institucionais. Não raro, superavam o formalismo das crenças, a oficialidade das liturgias e a sacramentalidade dos rituais.

Nesse universo de desafios e dúvidas, novas perguntas afloravam tanto em relação ao conhecimento científico e à tecnologia, quanto ao lugar do sagrado na contemporaneidade. As ciências “exatas” mostraram-se impotentes e incapazes de elaborar explicações objetivas e definitivas que substituíssem as complexas teias de relacionamentos e "infinitudes" que ocupavam as mentes humanas.

O “retorno", ou melhor, a permanência das práticas de (re)sacralização do mundo instigou intelectuais das áreas da sociologia, da história, da antropologia e da teologia a revisitar essa temática e a propor novas abordagens. Por meio delas buscavam superar as respostas “clássicas” e trazer à tona outras possibilidades de entendimento do sagrado ${ }^{3}$. Dentre tantos se destacam Émile Durkheim ${ }^{4}$, Rudolf Otto ${ }^{5}$, Mircea Eliade ${ }^{6}$, Roger Caillois ${ }^{7}$, cujos estudos contribuíram para a construção de diversas

3 Emile Durkheim, Marcel Maus, Roger Bastide, Georges Bataille, René Girard, Roger Caillois e muitos outros se debruçaram sobre o tema.

4 DURKHEIM, Emile. As formas elementares da vida religiosa. São Paulo: Martins Fontes, 1996.

5 OTTO, Rudolf. O sagrado. Lisboa: Ed. 70, 1992.

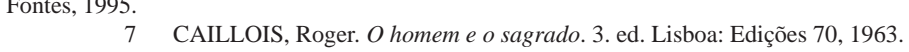


teorias que ajudaram a entender o significado de sagrado e sua permanência no cotidiano das pessoas e no interior das sociedades.

Submetida a várias origens etimológicas, considera-se que a palavra - sagrado - deriva do verbo latino “sacer”, isto é, designa o que não pode ser tocado, que é querido dos deuses, santo, venerável. Contempla a idéia de "sanctus", que corresponde ao que é tornado sagrado, inviolável, respeitável, virtuoso, poderoso. Como contraponto, outras concepções lhes dão um sentido oposto, tal como maldito, execrável, detestável, abominável. Por estas e por outras designações, o homem, ao vivenciar a essência desses múltiplos significados, reage de maneira aparentemente contraditória, com manifestações de respeito ou de aversão, de desejo ou de espanto, de amor ou de ódio.

Os gregos utilizavam o conceito de "hieros” para significar algo que era sagrado e que se referia ao divino, algo que era dotado de força e de luz. Em oposição ao "hieros", usavam o conceito de "hagios”, que continha a idéia de maldito. A religião judaica introduziu a contraposição entre "sagrado" e "profano”. Esta contraposição foi incorporada pelo cristianismo acrescentando-lhe a idéia de santidade de Deus e a de pecado.

No decorrer do século XX, Durkheim, Rudolf Otto, Mircea Eliade e Roger Caillois trabalharam o conceito de sagrado e, em muitas circunstâncias, o colocaram em oposição ao conceito de profano. Durkheim, já em 1912, ressaltava que:

Todas as crenças religiosas conhecidas, sejam simples ou complexas, apresentam um mesmo caráter comum: supõem uma classificação das coisas, reais ou ideais, que os homens concebem, em duas classes, em dois gêneros opostos, designados geralmente por dois termos distintos que as palavras sagrado e profano traduzem bastante bem. A divisão do mundo em dois domínios que compreendem, um, tudo o que é sagrado, outro, tudo o que é profano, tal é o traço distintivo do pensamento religioso: as crenças, os mitos, os gnomos, as lendas, são representações ou sistemas de representações que exprimem a natureza das coisas sagradas, as virtudes e os poderes que lhes são atribuídos, sua história, suas relações mútuas e com as coisas profanas. ${ }^{8}$ 
Pela análise de Durkheim, observa-se ainda que o sagrado é considerado como uma realidade antropológica, na medida em que todas as sociedades parecem ter desenvolvido essa concepção. Nessa perspectiva, o sentimento do sagrado teria origem na própria vida social. O que o homem religioso adora, por meio de sua religião, é a própria sociedade, seus valores, a sua visão de mundo. Assim, há a tendência de remeter para o campo do sagrado, tudo aquilo que se considera importante para a reprodução social. Desse modo, para ele, o sentimento e as atitudes para com o sagrado não se aplicariam apenas aos objetos religiosos, mas também a qualquer outra esfera da vida social, a exemplo das esferas cívica, familiar e amorosa.

O próprio Durkheim conclui que “a religião é uma coisa eminentemente social. As representações religiosas são representações coletivas que exprimem realidades coletivas; os ritos são maneiras de agir que só surgem no interior de grupos coordenados e se destinam a suscitar, manter ou refazer alguns estados mentais desses grupos". ${ }^{9}$

Gilberto Safra, referindo-se a Durkheim destaca que:

o sagrado é o traço essencial dos fenômenos religiosos, tratase de um sentido que se define pela oposição ao profano. Sagrado e profano falariam de dois mundos contrários, em torno dos quais gravita a vida religiosa. As coisas e seres sagrados, segundo ele, protegeriam o indivíduo e a comunidade das interdições, enquanto os seres e coisas profanas seriam os elementos submetidos às interdições, e só entrariam em contato com os primeiros através de ritos prescritos pela crença que sustenta essa divisão do mundo. O sagrado seria um anseio de potência, de uma energia que agiria sobre o profano. Este é um vértice no estudo da religiosidade que procura compreender a organização social, a partir de algumas categorias utilizadas como referenciais. ${ }^{10}$

Todavia, cabe ainda lembrar que embora opostos, separados e dissociados, sagrado e profano não são excludentes. Pois como afirma

9 Ibid., p. XVI.

10 SAFRA. Gilberto. A vivência do sagrado e a pessoa humana. Disponível em: <http:// br.groups.yahoo.com/group/a-ortodoxia-brasil/>. 
Durkheim, “a coisa sagrada é, por excelência, aquela que o profano não deve e não pode impunemente tocar. Claro que essa interdição não poderia chegar a ponto de tornar impossível toda a comunicação entre os dois mundos, pois, se o profano não pudesse de maneira nenhuma entrar em relação com o sagrado, este de nada serviria”, ${ }^{11}$

No seu livro, publicado em 1917, Rudolf Otto mostrou um sagrado que superava seu reduzido papel de construção social, sem as camadas racionalizadas, sem as narrativas teológicas e éticas. Segundo ele, “o sagrado é, antes de mais, uma categoria de interpretação e de avaliação, que, como tal, só existe no domínio religioso”. ${ }^{12}$ Uma categoria que contém elementos racionais e irracionais. Para se aproximar do fundamento irracional do sagrado, opta por outra categoria ou por um termo que se tornou paradigmático: “o numinoso”. Insiste ele:

Falo de uma categoria numinosa como uma categoria especial de interpretação e de avaliação e, da mesma maneira, de um estado de alma numinoso que se manifesta quando esta categoria se aplica, isto é, sempre que um objeto se concebe como numinoso. Esta categoria é absolutamente sui generis; como todo o dado originário e fundamental, é objeto de não definição no sentido estrito da palavra, mas somente de exame. ${ }^{13}$

O sagrado passa a ser compreendido, então, por seu caráter numinoso, inacessível ao pensamento racional. Renato Ortiz, ao analisar Otto, destaca que “o 'numen', foco de luz, se caracteriza pelo 'tremendum majestas', que provoca no homem o ‘sentimento de criatura’, isto é, o sentimento de sua aniquilação diante desta força divina fenomenal que lhe é exterior". ${ }^{14}$

Otto ainda acrescenta ao numinoso algo a mais e chama-o de "sentimento do estado de criatura, o sentimento da criatura que se abisma no seu próprio nada e desaparece perante o que está acima de toda a criatu-

11 DURKHEIM, op. cit., p. 23-24.

12 OTTO, R., op. cit., p. 13.

13 Ibid., p. 15.

14 ORTIZ, Renato. Religiões populares e indústria cultural. Religião e Sociedade, Rio de Janeiro, n. 5, p. 55, jun. 1980. 
ra”. ${ }^{15} \mathrm{E}$ destaca: “Uma vez que não é racional, isto é, que não pode desenvolver-se por conceitos, não podemos indicar o que é a não ser observando a reação do sentimento particular que o seu contato em nós provoca”. ${ }^{16}$ Percebe-se, portanto, que é um sentimento primário e que Otto o qualifica como misterium tremendum, que causa arrepios.

Na reflexão ottoniana, o conceito de numinoso é derivado de numem e significa aquilo que é próprio dos deuses e nele está o cerne irracional do sagrado em toda sua potência. Numen é algo totalmente distinto de qualquer outra experiência. Desta forma, o sagrado apresenta-se como uma realidade de ordem absolutamente diversa da realidade natural e se caracteriza como experiência do mysterium tremendum, e como vivência de terror perante o ser ou objeto sagrado. É uma categoria composta de elementos racionais e não racionais e, em ambos os casos, é uma categoria a priori, pois: “O sagrado, no sentido completo da palavra, é, portanto, para nós uma categoria composta. As partes que a compõem são, por um lado, os seus sentimentos racionais e, por outro, os seus elementos irracionais. Considerada em cada uma destas duas partes, ela é uma categoria puramente a priori. Importa manter esta afirmação perante todo o sensualismo e todo o evolucionismo. ${ }^{17}$

Sylvio Fausto Gil Filho destaca que

a teoria do sagrado ottoniana nos permite resguardar um atributo essencial para o fenômeno religioso ao mesmo tempo em que o torna operacional. Nesta abordagem, o sagrado reserva aspectos ditos racionais, ou seja, passíveis de uma apreensão conceitual através de seus predicados, e aspectos não racionais, que escapam à primeira apreensão, sendo exclusivamente captados enquanto sentimento religioso. ${ }^{18}$

Deste ponto de vista, as idéias racionais não vêm de nenhuma percepção sensível, existem na razão pura, são uma predisposição original do

15 OTTO, R., op. cit. p. 19.

16 Ibid. p. 21.

17 Ibid., p. 149.

18 GIL FILHO, Sylvio Fausto. Igreja católica romana: fronteiras do discurso e territorialidade do Sagrado. Curitiba, 2002. Tese (Doutorado) Universiade Federal do Paraná. 
espírito. Por esta razão, o homem moderno, ao tentar racionalizar o sagrado, perdeu o significado mais profundo da sacralidade, dado que ela constitui uma das dimensões mais intangíveis e irrecusáveis do homem. Assim, o sagrado implica na luta entre o mysterium e o tremendo, o temor e o tremor. A luta entre o amor e o ódio, Deus e o diabo. O mysterium conduz ao admirável, ao assombroso, ao pasmo, à contemplação.

O mistério pode ser conceituado como aquilo que está escondido, que não é manifesto, que não é concebido nem compreendido; é o extraordinário e o estranho, sem indicar com precisão a qualidade ${ }^{19}$. O mysterium entendido como o suave fluxo do espírito ou como algo feroz, demoníaco ou como a formosura de um arroubo da alma. O tremendo é o absolutamente inacessível, poderoso e arrebatador, que se complementa pela idéia de poder, de força e de preponderância absoluta.

A estas qualificações Otto denomina de “majestas” e destaca que "o elemento do tremendum encontra uma expressão que parece mais adequada na fórmula: ‘tremenda majestas'”, ${ }^{20}$

O tremendum e a majestas implicam num terceiro elemento que Otto qualifica como "energia” do numinoso, que se faz sentir na "orgê” à qual se referem as expressões simbólicas de vida, de paixão, de sensibilidade, de vontade, de força, de movimento e de excitação de atividade de impulso. ${ }^{21}$

O sentimento da majestas transmite a sensação de anulação da própria vida e da onipotência da transcendência. É a impressão do poder irrestrito do "completamente outro". O mysterium tremendum tem como complementação e oposição o "fascinans”, cujas representações racionais e as noções que acompanham e esquematizam este elemento irracional são o amor, a compaixão, a piedade e a benevolência. ${ }^{22}$

Enquanto Rudolf Otto desenvolvia o conceito do numinoso como cerne irracional do sagrado em toda sua potência, Mircea Eliade preferiu estudá-lo na sua totalidade. Por esta razão diz que "a primeira definição que pode dar-se ao sagrado, é que ele se opõe ao profano”. ${ }^{23}$ Destaca que o 
homem toma conhecimento do sagrado porque este se manifesta, se mostra como qualquer coisa de absolutamente diferente do profano, por meio das hierofanias, no sentido de que algo de sagrado se nos mostra. ${ }^{24}$

Assim, a percepção do sagrado em objetos é diferente daquela que tradicionalmente se manifesta na realidade ou na ordem natural das coisas. E, embora elas possam parecer estranhas ao homem moderno, adquirem significado próprio por meio das hierofanias. Os objetos, sejam eles pedras, árvores, animais ou minerais, adquirem, por meio das hierofanias, características que os sacralizam e, por isso, somam, àquelas que lhes são naturais, outras - as sagradas. Eliade destaca que:

Nunca será demais insistir no paradoxo que toda a hierofania constitui, até a mais elementar. Manifestando o sagrado, um objeto qualquer se torna outra coisa, e, contudo, continua a ser ele mesmo, porque continua a participar do seu meio cósmico envolvente. Uma pedra sagrada, nem por isso é menos pedra; aparentemente (com maior exatidão: de um ponto de vista profano) nada a distingue de todas as demais pedras. Para aqueles a cujos olhos uma pedra se revela sagrada, a sua realidade imediata transmuda-se numa realidade sobrenatural. ${ }^{25}$

Ressalta que, para o homem moderno, sagrado e profano constituem duas modalidades de ser no mundo, duas situações existenciais assumidas pelo homem ao longo de sua história. Elas dependem das diferentes posições que ele conquistou no cosmos. Por isso, o sagrado requer um espaço sagrado que provém da própria criação do mundo e da busca de um sentido para o universo.

Percebe-se, portanto, que para Mircea Eliade, além de uma categoria religiosa, o sagrado é também um princípio filosófico de compreensão do homem no mundo. Por esta razão, é mostrado como o completamente outro que transcende a qualquer ente profano e pode estar presente em lugares, em pessoas ou objetos, no tempo, sob a forma de hierofanias. Algumas delas possuem um caráter universal, outras local ou regional. Ambas são entendidas pelo homem como forma de imanência do divino. Eliade

24 Id.

25 Ibid., p. 26 
escreve: "Temos que nos acostumar a aceitar as hierofanias em qualquer lugar, em qualquer área da vida fisiológica, econômica, espiritual e social. Na verdade, não sabemos se não existe algo - objeto, ação, procedimento fisiológico, ente, um jogo etc. - que nunca, em algum momento da história humana, havia sido transfigurado numa hierofania”. ${ }^{26}$

Ele ainda chama atenção para um aspecto realmente curioso quando diz que: "O que é paradoxal e não entendível não é o fato da manifestação do sagrado em pedras ou árvores, mas o fato é que ele se manifesta e desta maneira limita e relativiza”. ${ }^{27}$

Para Pedro Ribeiro de Oliveira:

Eliade parte da suposição da existência do Sagrado como uma realidade que se manifesta por si mesma (daí todo o cosmos poder ser visto como sacramento). Não é por acaso que seu conceito chave é o de hierofania: o sagrado que, enquanto sujeito da ação, manifesta-se ao ser humano. A este só cabe desvelar o mistério do sagrado, a menos que, tendo abandonado a sua condição religiosa, dessacralize o mundo ao negar-lhe qualquer significação mistérica. ${ }^{28}$

\section{Ressalta ainda que se trata}

sempre do mesmo ato misterioso: a manifestação de alguma coisa inteiramente outra, de uma realidade que não pertence ao nosso mundo, nos objetos que fazem parte integrante do nosso mundo natural e profano". Essa atribuição da iniciativa de manifestação ao Sagrado, contudo, não invalida seu estudo comparado das concepções de espaço, tempo, cosmos e de vida humana, uma vez que não é necessário postular o sagrado como sujeito da manifestação para entender a experiência religiosa. ${ }^{29}$

26 ELIADE, M. Die Religionen und das Heilige. Apud BRÜSEKE, Franz. O sagrado na modernidade técnica. Cadernos de pesquisa interdisciplinar em Ciências Humanas, Florianópolis, n. 70, p. 12, maio 2005.

27 ELIADE, M., op. cit., p. 12.

28 OLIVEIRA, Pedro Ribeiro. Religiosidade: conceito para as Ciências do Social. Ceprelc/ UCB, 1999.

29 Id. 
Eliade complementou suas análise na entrevista autobiográfica que concedeu a Claude Henri-Rocquet. Na oportunidade o entrevistador perguntou-lhe: afinal, o que entende por sagrado? Eliade respondeu:

Como delimitar o sagrado? É muito difícil. O que me parece inteiramente impossível, em todo o caso, é imaginar como o espírito humano poderia funcionar sem a convicção de que existe qualquer coisa de irredutivelmente real no mundo. É impossível imaginar como a consciência poderia aparecer sem conferir uma significação aos impulsos e às experiências do homem. A consciência de um mundo real e significativo está intimamente ligada à descoberta do sagrado. Pela experiência do sagrado, o espírito apreendeu a diferença entre o que se revela como real, poderoso, rico e significativo, e o que é desprovido dessas qualidades, a saber, o fluxo caótico e perigoso das coisas, as suas aparições e os seus desaparecimentos fortuitos e vazios de sentido. Mas é preciso ainda insistir sobre este ponto: o sagrado não é um estádio na história da consciência, é um elemento na estrutura desta consciência. Nos graus mais arcaicos de cultura, viver enquanto ser humano é, em si, um ato religioso, pois a alimentação, a vida sexual e o trabalho têm um valor sacramental. A experiência do sagrado é inerente ao modo de ser do homem no mundo. Sem a experiência do real - e do que não o é -, o ser humano não saberia construirse [...] O sagrado não implica a crença em Deus, nos deuses ou em espíritos. É, repito-o, a experiência de uma realidade e a fonte da consciência de se existir no mundo. ${ }^{30}$

Portanto, o que se pode constatar é que o sagrado se constitui na expressão da relação constitutiva da consciência humana com o mundo que a envolve. O que está em causa na noção de sagrado é o próprio enraizamento da consciência no interior de um mundo que a transcende. Sagrado como “a experiência da realidade” que se oferece à consciência quando o homem se descobre como ser no mundo.

Por sua vez, Roger Caillois também parte da tese de que qualquer definição de religião implica na oposição entre sagrado e profano e que o

30 CORREIA, João Carlos. Religiões e compaixão. Cadernos ISTA (Instituto S. Tomás de Aquino), Lisboa, n. 5, 2002. 
homem religioso pode agir sem angústia ou temor ou com um sentimento de dependência íntima que retém, contém e dirige cada um dos seus impulsos.

Assim, "qualquer concepção religiosa do mundo implica a distinção do sagrado e do profano, opõe ao mundo em que o fiel se entrega livremente às suas ocupações, exerce uma atividade sem conseqüências para a sua salvação, um domínio onde o temor e a esperança o paralisam alternadamente, onde, como à beira de um precipício, o mínimo desvio no mínimo gesto pode perdê-lo irremediavelmente". ${ }^{31}$

E, ao destacar os caracteres principais do sagrado, aproxima-se de Eliade quando afirma que "o sagrado pertence, como uma propriedade estável ou efêmera, a certas coisas (os instrumentos de culto), a certos seres (o rei, o sacerdote), a certos espaços (o templo, a igreja), a certos tempos (o domingo, o dia da páscoa, o natal). ${ }^{32} \mathrm{O}$ sagrado pode estar presente em todas as coisas.

Coisas, lugares, tempos, eventos, ações, pessoas, comunidades, enfim, a vida como um todo, podem ser considerados sagrados (santos) e constituídos como objeto de devoção e culto e muitas vezes são separados fisicamente por muros ou por outras formas, tornando-se assim locais reservados ou com acessos restritos. Para o autor, essa separação é necessária uma vez que o sagrado não deve ser contaminado pelo profano, pois a sua presença degrada e arruína, destrói a bênção divina. Retira-se do lugar sagrado tudo o que pertence ao mundo profano para que ele não perca sua eficácia. Por esta razão, assinala que "sem dúvida, em relação ao sagrado, o profano não está apenas impregnado de características negativas: parece, em comparação com aquele, tão pobre e desprovido de existência como o nada perante o ser. (...) Convém, pois, que certas divisórias estanques garantam um isolamento perfeito do sagrado e do profano: qualquer contato é fatal quer a um quer ao outro". ${ }^{33}$

Ainda em relação ao profano e ao sagrado, Caillois cita Durkheim quando este diz que "os dois gêneros (...) não podem aproximar-se e preservar ao mesmo tempo a sua natureza própria”; acrescenta, porém que ambos

31 CAILLOIS, R., op. cit., p. 19.

32 Ibid., p. 20.

33 Ibid., p. 21-22. 
são "necessários ao desenvolvimento da vida: um como meio onde ela se desdobra, o outro como a fonte inesgotável que a cria, que a mantém, que a renova". 34

Todavia, também ressalta que é do sagrado que o crente espera todo o socorro e todo o êxito. O respeito que lhe devota é composto de terror e de confiança. Pouco importa a forma que ele assume, quer seja uma divindade ou a alma dos mortos, uma divindade difusa ou força desconhecida. Ele possui o dom da fascinação. Destaca que, "sob sua forma elementar, o sagrado representa, pois, acima de tudo, uma energia perigosa, incompreensível, arduamente, manejável, eminentemente eficaz”. ${ }^{35}$

E ressalta que, numa relação direta:

o domínio do profano apresenta-se como o do uso comum, o dos gestos que não exigem precaução alguma e que se conservam dentro da margem, por vezes estreita, deixada ao homem para exercer sem constrangimento a sua atividade. $\mathrm{O}$ mundo do sagrado, ao invés, aparece como o do perigoso ou do proibido: o indivíduo não pode aproximar-se dele sem pôr em movimento certas forças de que não é senhor e perante as quais a sua fraqueza se sente desarmada. Todavia, sem o seu recurso, não há ambição que se não veja voltada ao fracasso. ${ }^{36}$

As considerações de Durkheim, Otto, Eliade e Caillois remetem às questões colocadas no início deste texto. E, se não cabem questionamentos quanto ao fato do conhecimento científico se caracterizar pela objetividade e do pensamento filosófico ser orientado por princípios racionais, quanto às contribuições da ciência e da filosofia ao processo de humanização é forçoso observar que persiste a relação do humano com o transcendente.

Todavia, pode-se destacar que o homem é um ser de relações e se encontra imerso na provisoriedade. E, para dar alguma solidez a ela, busca formas diversas de se relacionar com a natureza, com a sociedade e com o transcendente. A sensação de desencantamento com o mundo provocada pelo avanço da racionalidade científica fez com que novas formas de en-

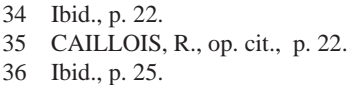


cantamento surgissem e se infiltrassem no comportamento e na organização da sociedade e se revelassem tanto sob a forma de devoção quanto de resistência.

Por isso, o esforço para explicar o sentido da vida ou da morte está impregnado de mecanismos que refletem a importância de se manter um contato constante com o transcendente, o qual, muitas vezes, se materializa em diferentes concepções religiosas. As mudanças necessárias à construção do humano exigem também a transformação das subjetividades pessoais e coletivas, buscando, a cada dia, um sentido novo para o viver. E, se a presença da religiosidade é uma constante nesta trajetória, ela se fundamenta na percepção da existência de forças superiores e na esperança de uma vida mais forte que a morte. Percepção e esperança que se expressam nos ritos, nos mitos e no conjunto dos sistemas simbólicos que, além de desenhar uma imagem do mundo, também esboçam uma relação entre imanência e transcendência e que, por meio dela, o homem poderia transpor sua temporalidade e realizar sua experiência mística.

Sob diferentes formas de manifestação, pode-se considerar que o sagrado está presente no cotidiano das sociedades independentemente da sua aceitação ou das crenças individuais. Na sua maneira de ser, ele supõe uma (re)ligação com o mundo, define-se como uma totalidade de sentido integradora do humano e que lhe confere um certo grau de inteligibilidade. O sagrado é, assim, o sentimento religioso que aflora e que provoca sentimentos múltiplos; é um estágio intrínseco à estrutura da subjetividade humana.

O homem contemporâneo, assediado pelo desencantamento com o mundo, é instado a enfrentar a realidade da vida sem deuses e sem profetas e a superar a crise de valores e a fragmentação das certezas. O risco é a possibilidade do esvaziamento dos espaços das sociabilidades naturais para uma busca de refúgio no reino da transcendência, na vida mística ou na fraternidade das relações humanas diretas e pessoais.

No interior dessas reflexões aflora, necessariamente, o tema da religião e da religiosidade. Sem pensar em esgotar qualquer um desses dois conceitos, pode-se considerar a religião como o conjunto das atitudes e atos pelos quais o homem se prende e se liga ao divino ou manifesta sua dependência em relação a seres invisíveis tidos como sobrenaturais. Por sua vez, a religiosidade é vista como um comportamento pessoal e intransmissível, alheia ao debate, às igrejas, às instituições religiosas. 
Em ambas as manifestações, o rito torna-se essencial pela ligação que estabelece com o sagrado. De maneira simplificada pode-se dizer que o rito é a práxis do mito. É o mito em ação. Enquanto o mito rememora, o rito comemora. O rito abole o tempo profano, cronológico, é linear e, por isso mesmo, irreversível. Os limites entre o sagrado e o profano, entre o rito religioso e a festa estão muito próximos.

Cabe observar, também, que se a visibilidade dessas práticas, na maioria das vezes, é controlada por instituições ou por coletividades religiosas, e se o sagrado exige, sobretudo, experiência e sentimento, nada melhor do que entendê-lo a partir das vivências da religiosidade, sobretudo daquelas que se desenvolvem a par das instituições religiosas ou das fórmulas previamente estabelecidas e autorizadas.

Ao se olhar para a sociedade brasileira, instrumentalizados pelas reflexões acima expostas, observa-se que ao lado das práticas e dos rituais definidos pela hierarquia, da clericalização do culto e do controle sobre o templo, encontra-se uma religiosidade que evoluiu independente das prescrições oficiais e que é aceita pela população como uma das mediações entre ela e o sagrado. É ela que estabelece um relacionamento direto com o sagrado, uma manifestação espontânea da fé e da crença e uma ritualística na qual, no relacionamento com o transcendente, somam-se forma e emoção.

Socialmente, essa religiosidade recorta verticalmente a sociedade, perpassando por diferentes categorias sociais, sem levar em conta se são pobres ou ricos, analfabetos ou escolarizados. Ela se distingue de uma religiosidade oficial, ditada e controlada por especialistas, sejam eles clericalizados ou não.

Nas manifestações desta religiosidade cumpre-se uma das características descritas na concepção de sagrado: de um lado, observa-se a crença nos espíritos bons, aceitos e respeitados, que fazem o bem, que ajudam e que fazem a felicidade das pessoas; de outro, a adesão aos espíritos perigosos que fazem o mal, que prejudicam os homens e que levam as pessoas à perdição. Ambos refletem a experiência do “misterium”, do numinoso e do não racional. Ambos geram rituais e práticas que povoam o imaginário individual e social.

Curioso é observar que, embora antagônicos, bem e mal se colocam como indispensáveis um ao outro, sendo que o primeiro não subsiste sem o segundo. Pratica-se o bem porque existe o mal, veneram-se santos e 
espíritos bons porque existem os maus. Os opostos encontram-se numa dimensão comum: ambos expressam a crença no sagrado, nas maneiras como ele se manifesta e na forma como difere do que é profano.

A subsistência desse relacionamento direto com o sagrado, da coexistência dos opostos, pode ser observada, com certa facilidade, nos caminhos das práticas e rituais religiosos percorridos pela sociedade brasileira desde o início da colonização. Dominada por um catolicismo aceito como oficial, marcada por uma liturgia sacramental vinculada ao templo, a tendência da oferta dos bens religiosos seria a de se manter exclusivamente no nível do que era permissível e autorizado pelas autoridades clericais e governamentais.

Todavia, fruto da complexidade religiosa e cultural, às múltiplas experiências de uma catolicidade oficial européia somaram-se outras representações religiosas, a dos nativos e a dos afrodescendentes, constituindo-se um conjunto de concepções e explicações que sobrepunham racional e irracional, sagrado e profano, espiritual e material. O conjunto das representações construídas e as experiências vividas seja pelo caráter sacramental da religiosidade, seja pelo santorial, pelas pajelanças, pelos cultos afros, pela crença nas forças sagradas da natureza, pela interveniência dos espíritos desencarnados, formou um cabedal religioso próprio, constituído de formas específicas de relacionamento com o sagrado. Não se trata de um mero sincretismo religioso ou da sobreposição de rituais e crenças, mas da construção de uma religiosidade vivenciada nas suas crenças, nos seus ritos e nos santos de sua fé. Como diz Otto, foi e é uma "experiência do sagrado" sem necessidade de intermediação, de fórmulas prontas e estáticas.

Ao institucional somaram-se diferentes rituais e múltiplas formas de representar e externar a fé e de se relacionar com “santo”, elegeram-se novos espaços e aceitaram-se outras modalidades de manifestação do sagrado. Aos rituais coletivos agregou-se um conjunto de procedimentos de ordem pessoal, que expressava sentimentos que não dependiam da coletividade e nem necessitavam de socialização para subsistirem. Por isso, são próprias da intimidade das pessoas e sua exteriorização ou as lógicas conceituais não constituem elemento essencial de compreensão e são mantidos sem necessidade de engajamento em rituais pré-definidos.

Há, portanto, que se distinguir duas situações: de um lado, a manifestação da religiosidade, da crença e da fé. E de outro, as múltiplas pos- 
sibilidades de sua interpretação. Não raro prevalece o desejo de quem quer interpretar o fato sobre a realidade de quem o vivencia. É mais importante dizer o que as práticas e rituais significam do que aceitá-los como uma forma de representar e vivenciar o sagrado. A racionalidade conceitual impõe significados que nem sempre respeitam a lógica que significa e ressignifica realidades, diálogos entre o humano e o transcendente, o material e o espiritual, o homem e seu além, seja ele santo, divino ou demoníaco.

Essa crença e essas diferentes formas de manifestar a religiosidade independem de hierarquias institucionais, da clericalização dos hábitos, das compreensões exteriores da teologia, da filosofia e da sociologia. Não necessitam de avalistas coletivos, de interpretações institucionalizadas e aceitações grupais. Elas subsistem porque são a expressão da vivência do sagrado que independe de confirmações teórico-conceituais.

Além disso, a pluralidade de vivências do sagrado nem sempre representa uma ruptura ou oposição a qualquer forma de religiosidade oficial. No Brasil, circunstâncias internas e externas, número reduzido de sacerdotes, distâncias intransponíveis, dificuldades de comunicação, desde os tempos remotos inviabilizavam o acesso da população católica aos rituais oficiais conduzidos pelo clero. Como resultado dessas circunstâncias, a presença dos padres era esporádica e quando ocorria era muito rápida para dar conta de todos serviços demandados pelos fiéis. Com isso, significativa parcela dos rituais católicos passou a ser conduzida por rezadores, os quais, além de sua precária formação, pouco se relacionavam com a hierarquia da igreja. Constituiu-se, então, uma religiosidade que foi transmitida pela oralidade e sustentada em saberes pouco afeitos aos princípios da teologia ou da escolaridade organizada.

A ausência do clero, a simplicidade de quem dirigia o culto, a evolução e consolidação de formas paralelas de crença e o informalismo das práticas ritualísticas contribuíram para o surgimento de uma fé e uma religiosidade local, muitas vezes desvinculada da oficial e estruturou um catolicismo distante daquele pregado pelo concílio de Trento e daquele que a hierarquia desejava para o Brasil. Embora se tenha instituído o mito do Brasil católico, não há como negar que a estrutura do catolicismo aqui implantada contribuiu para a constituição de um país de religiosidade múltipla, multifacetada e diferenciada. 
No decorrer do século XIX e início do XX, observa-se um esforço da hierarquia católica na busca da "purificação" da religião, com uma ampla reforma dos rituais, do clero e do culto. Implantou-se uma política de controle dos locais de culto, dos centros de peregrinação, da oficialização da crença e da institucionalização das relações com o sagrado. Ao observar essa diversidade de ritos e um “certo descontrole” do culto, os bispos canalizaram seus esforços na reforma e no controle das cerimônias e dos ofícios da religião. Por meio dessa nova maneira de atuar, conhecida como a romanização do catolicismo no Brasil, produziu-se um rico material escrito, divulgado em documentos e cartas pastorais, organizaram-se vários congressos católicos, convocaram-se reuniões episcopais, redigiram-se catecismos e adotaram-se novas devoções e rezas. Sua implantação foi lenta e gradual e, na prática, os efeitos foram limitados, pois não conseguiu impedir a continuidade das formas paralelas de catolicismo e de religiosidade espontânea e não substituiu a maneira como comunidades católicas expressavam sua tradição e fé católica por meio de rituais sem o controle da hierarquia.

A natureza liberal das práticas religiosas seculares consolidou uma forma de crença sem restrições e privações. Uma mistura de ritos sagrados com festas profanas, práticas sacramentais e procissões, círios e festas do arraial construíram espaços de convivência entre o sagrado e o profano sem oposições, sem constrangimentos, sem riscos e sem penalidades. Formavase uma simbiose entre o que é de Deus e o que é do homem, entre a reza e o baile, entre a água benta e a bebida alcoólica. O santo merecia todas as homenagens: a reza, a festa, a missa, a doação. Mas ao homenageá-lo também se abria espaço para o profano: a dança, o namoro, a briga, os torneios e o jogo. Uma composição entre sagrado e profano, um grande espaço de realização e de convivência entre o hieros e o hagios.

Esta sociabilidade sócio-religiosa ocorria com ou sem a presença do padre. Se este não pudesse presidir as cerimônias, o rezador cumpriria a tarefa, enquanto o festeiro se encarregaria das homenagens profanas. Neste contexto, gradativamente desenhou-se um novo ordenamento da condução das práticas litúrgicas. Enquanto os padres se encarregavam daqueles ofícios sacramentais que eram de sua exclusiva competência como, por exemplo, rezar missa, batizar, casar, confessar e demais sacramentos, a reza do terço, as ladainhas, as bênçãos, as cantorias, as procissões, os cultos, o cuidar dos 
lugares sagrados e as outras providências demandadas para a manutenção do culto local poderiam, perfeitamente, ser conduzidas por pessoas da comunidade, por rezadores e rezadeiras, ou por benzedores e benzedeiras. Sua proximidade com as coisas do sagrado, além de atender aos seus próprios desejos e às suas necessidades religiosas, também contribuía para melhor compreender as sensibilidades religiosas e os sentimentos de fé dos moradores da região. Desta maneira, há que se dizer que o santo aceitava muitos intermediários, inclusive alguns mais próximos da realidade dos devotos.

Essa liberdade contribuiu para a construção de uma forma de religiosidade cuja originalidade se manifestava tanto nas experiências pessoais com o sagrado, quanto na sua socialização por meio de comemorações festivas em homenagem aos santos protetores pessoais ou locais. Fogos, danças, culto às imagens, devoções a santos domésticos, evocação de orixás, “catolicização” de entidades cultuadas por outras crenças, adequação das rezas e benzimentos, popularização de crendices e santificação de lugares e pessoas compunham uma ritualística sacroprofânica, na qual a sacralidade e a profanidade prescindiam de oficialização e autorização de instituições religiosas ou do estado.

O componente lúdico e o caráter festivo das práticas, além de quebrar a monotonia da vida cotidiana, constituíam-se nas poucas oportunidades de diversão e distração das populações mais distantes dos grandes centros urbanos (embora elas ocorressem também nas capitais), e revelavam que o sagrado e o profano, apesar de distintos, não se opunham e nem se excluíam. Ambos constituíam a motivação para a festa e a devoção, pois organizar e participar da festa não era apenas trabalho e lazer, mas era uma das maneiras de se dedicar ao santo, mostrar seu reconhecimento e agradecimento e a ele continuar vinculado.

Essa religiosidade capaz de gerar identidades e inserções sociais também aproximava altar e salão, rito e mito, oração e riso, fé e festa, devoção e favor, doação e pedido, tudo num grande cenário de encontros, de alegrias, de choros, de esperanças e de pedidos de novas graças. Vivência do sagrado, interesses materiais, festejos coletivos, dramaticidades espiritualizadas, divertimentos públicos e realizações pessoais traduziam momentos de intimidade e reciprocidade entre a religião e a pessoa. A fantasia e a realidade, o delírio e o sentimento, a representação e a transgres- 
são, a liberdade e a doação, a identidade cultural e a afirmação de valores construíam uma linguagem que não necessitava de explicações e de regras porque era absolutamente familiar àqueles que participavam desse grande cerimonial religioso-profano.

Isso permite perceber que no imaginário religioso há um mútuo comprometimento. Do lado dos homens a devoção, a oração, o rito, a obediência, a festa e uma infinidade de atos. Do lado do santo o cuidar, a graça, a proteção e a salvação. Essa mutualidade pode ser observada concretamente no culto a Nossa Senhora da Conceição por parte dos senhores e Nossa Senhora do Rosário pelos habitantes da senzala, embora Nossa Senhora fosse uma só. A tradição ensina que Santa Ana, mãe de Nossa Senhora e avó de Jesus, cuida dos pequenos, Santo Antônio se encarrega dos namoros e casamentos, São Longuinho ajuda a encontrar objetos perdidos, São José protege os operários, São Cristóvão cuida dos transportadores, Santa Rita resolve as causas impossíveis e São Pedro detém as chaves da porta do céu. Nenhum deles distingue ricos e pobres. Nenhum deles se preocupa com cor, fronteira geográfica ou idade física.

Nesse conjunto de intimidades, o sagrado não precisa de regras e sua compreensão não necessita de racionalidades. E se a tecnologia facilita a vida material, a física explica as reações da matéria, a matemática calcula as dimensões e os espaços do universo, a filosofia se encarrega de matar os deuses, o sagrado permanece como possibilidade de diminuir o peso da transcendência e, embora não explique, facilita a relação com a finitude da existência humana. 